\title{
Anti-Cysticercus Antibodies in Pigs and Pig Breeders in María La Baja, Colombia
}

\author{
Mavianis Pinilla ${ }^{1}$, Julio C. Giraldo ${ }^{2}$, Lucy M. Villafañe ${ }^{1}$ Jaime Lorduy $^{1}$, Sandy Rocha ${ }^{3}$, \\ Cindy Rocha ${ }^{3} \&$ Aydali Meléndez ${ }^{3}$ \\ ${ }^{1}$ Corporación Universitaria Rafael Núñez, Cartagena, Colombia \\ ${ }^{2}$ Universidad INCCA de Colombia, Bogotá, Colombia \\ ${ }^{3}$ Cartagena, Colombia
}

Correspondence: Lucy Villafañe, Programa de Bacteriología, Corporación Universitaria Rafael Núñez, Cartagena, Colombia, Centro, Calle de La Soledad, No. 5-70, Colombia. Tel: 660-7777 ext. 108-324-325. Cel.: 312-822-2257. E-mail: lucy.villafane@curnvirtual.edu.co; villafanelucy@yahoo.com

Received: March 21, 2018 Accepted: April 26, 2018 Online Published: May 25, 2018

doi:10.5539/gjhs.v10n7p1 URL: https://doi.org/10.5539/gjhs.v10n7p1

\begin{abstract}
Cysticercosis is a parasitic infection caused by the larvae of the pork tapeworm, Taenia solium. It is acquired through fecal-oral contamination, and it can affect humans and pigs. In Colombia, this is an endemic infection especially in locations where breeding and commercialization of pigs are performed under poorly hygienic conditions, such as in Maria La Baja, Department of Bolívar. However, seroprevalence of anti-cysticercus antibodies in pigs or pig breeders at these locations has not been determined. Thus, using indirect immunoassays we quantified anti-cysticercus antibodies in serum samples of pigs $(n=254)$ and pig breeders $(n=121)$ in Maria La Baja. Furthermore, a questionnaire was applied in order to determine environmental, cultural, and socioeconomic variables. Anti-cysticercus antibodies were detected in 36.6\% (93/254) of pigs and 44.6\% (54/121) of pig breeders. A significant causal association was identified for daily cleaning of pigsties and having anti-cysticercus antibodies with an aOR $=15.16$ (CI 95\%: 2.13 - 107.86; $\mathrm{p}=0.0002$ ). No significant associations were identified between the evaluated variables and seroprevalence of anti-cysticercus antibodies in pigs. Our study indicates that there is a high seroprevalence of anti-cysticercus antibodies in humans and pigs in locations where handling of pigs is performed under poor hygienic conditions. Our results suggest that there is a need to design and implement prevention and control strategies in Maria La Baja in order to reduce transmission of this disease.
\end{abstract}

Keywords: antibodies, cysticercosis, swine, humans, population, risk factors (MeSH)

\section{Introduction}

Human and porcine cysticercosis is acquired by the ingestion of food or water contaminated with human feces containing Taenia solium cysts. In humans, these cysts develop into larvae that invade subcutaneous, skeletal muscle, and cardiac tissues. Additionally, it can also affect the central nervous system (CNS), and may lead to seizures, hydrocephaly, focal neurological deficits, and psychiatric disorders that involve physical and/or mental disability with high risk of death. On the other hand, infected pigs may be asymptomatic or present vomiting, diarrhea, and paralysis.

Cysticercosis is endemic in most underdeveloped countries (Rojas et al., 2007). The World Health Organization has estimated that over $80 \%$ of the 50 million people in the world suffering from epilepsy are in low-income countries. Furthermore, cysticercosis is considered one of the 14 neglected tropical diseases mainly in rural areas where porcine breeding and commercialization frequently take place under poor hygienic conditions (Flórez et al., 2013; Vásquez, Giraldo, Agúdelo, Campo, \& Vergara, 2011; Serrano, Prada, Nicholls, Duque, \& López, 1993).

Several studies have reported that cysticercosis is endemic in Colombian populations where domestic porcine breeding and commercialization under poor hygienic conditions are frequent, and even though this parasitic disease is a public health issue, mechanisms controlling porcine breeding and commercialization are seldom (Organización Mundial de la Salud [OMS], 2016; Zamora, 2015). The Colombian National Health Institute reported that between 2008 and 2013, seroprevalence of cysticercosis was of $8.55 \%$ in 23 of 32 of the Colombian departments. Some factors that favor this infection include reproduction of pigs under conditions that favor contact 
with contaminated human feces, ingestion of unwashed vegetables, selling pork meat without sanitary control, handling and consuming raw or not fully cooked pork meat in public spaces (Flórez et al., 2013; Vásquez et al., 2011; Agudelo \& Palacios, 2003). In addition, studies on porcine cysticercosis in Colombia have reported a prevalence that ranges from $6.82 \%$ to $37.5 \%$ (Vásquez et al., 2011; Serrano et al., 1993; Giraldo, Riaño, \& Vásquez, 2017).

In María La Baja (Department of Bolívar), pig breeding is an important economic activity performed by many as a way to earn a living. To our knowledge, there are no studies to date addressing anti-cysticercus antibodies in pigs and pig breeders in these populations even though they are under conditions that favor infection with this parasite. Therefore, in this study we determined anti-cysticercus seroprevalence in pigs and their breeders, as well as associated risk factors, in order to better understand the epidemiology of this disease that may contribute to improve epidemiological surveillance, prevention, and control of infection with Taenia solium.

\section{Methods}

\subsection{Participating Population}

The municipality of María La Baja, Department of Bolívar- Colombia, is located in the northern part of Colombia, with a population of 52.621 , and a total area of $547 \mathrm{Km}^{2}$ that are distributed into rural and urban areas. Breeding of pigs is an important economical activity in this municipality, and pigsties are usually located in the backyard of the households (Alcaldía Municipal de María La Baja Bolívar, 2017).

\subsection{Sampling}

This was a cross-sectional study with a correlational design. Sample size was calculated using the finite population formula with a 95\% CI, and 5\% error. Participants were selected at three different areas in Maria La Baja where pig breeding is frequent: Puerto Santander, El Silencio, and Solatapa (dates were provided by the Municipal Agricultural Technical Assistance Unit of Maria La Baja, UMATA). One pigsty was found in each household. A total of 109 households were selected by simple random sampling. A total of 254 pigs, and 121 breeders were tested.

During scheduled home visits, participants provided informed consent and completed a questionnaire evaluating environmental, sanitary, cultural, and socioeconomic conditions.

In both human beings and pigs, a sample of $5 \mathrm{ml}$ of peripheral blood was drawn in order to quantify anti-cysticercus antibodies (IgG). Sera was isolated and kept cold at $-4^{\circ} \mathrm{C}$ until analysis.

Serologic testing was performed by the Tropical Microbiology and Parasitology Group at INCCA de Colombia University, Bogota DC, using an indirect Elisa immunoassay that has been previously standardized and described by this group (Vásquez et al., 2011; Giraldo, Riaño \& Vasquez, 2017, Giraldo, Piragauta, Castañeda, Burgos, \& Marinkelle, 2000).

\subsection{Statistical Analysis}

Statistical analysis was performed using Windows SPSS v.19 software. For bivariate analysis, the association between presence of anti-cysticercus antibodies and risk factors was evaluated using Chi-square test. An odds ratio (OR) was calculated using a 95\% confidence interval, and an adjusted OR (aOR) was calculated in order to control for bias. A p-value $\leq 0.05$ was considered statistically significant.

\subsection{Ethics}

This study was approved by the Corporación Universitaria Rafael Núnezz Ethics Committee, Cartagena de Indias, according to Resolution 8430 of the Colombian Ministry of Health, law 84/1989, and the Helsinki Declaration (1975, modified in 2008).

\section{Results}

A total of 109 households were visited in the following areas of Maria La Baja: Puerto Santander, El Silencio, and Solatapa. The majority of breeders were women $(61 \%, 74 / 121$ CI $95 \% 52.3-69.4)$, and half of them (50\%) were between 21 and 43 years of age. Most breeders (88.4\%) resided in urban areas (107/121 CI 95\% 81.5-93), and the remaining $11.6 \%(14 / 121 \mathrm{CI} 95 \% 7.0-18.5)$ resided in rural areas.

Regarding socioeconomic variables, $85 \%$ of the breeders had access to healthcare through subsidized regime $(103 / 121$ CI $95 \% 77.7$ - 90.4) (Table 1). With regards to sanitary characteristics, $43.8 \%$ of breeders $(53 / 121$ CI $95 \%$ 35.3 - 52.7) took care of the bathing of the pigs, and $36.4 \%$ (44/121 CI95\% 28.3- 45.2) of breeders did it on a weekly basis (Table 1). The study population frequently disposed of human feces on an open field around the households, which is usually where the pigsties are located (Table 1). One of the main cultural characteristics 
identified was that $90.9 \%$ of participants preferred to eat pork meat (110/121, CI 95\% $84.5-94.9)$.

Table 1. Evaluated variables in pig breeders

\begin{tabular}{|c|c|c|c|}
\hline Socioeconomic characteristics & & Frequency & Percentage (\%) \\
\hline \multirow{4}{*}{ Occupation } & Independent worker & 60 & 49.6 \\
\hline & Unemployed & 26 & 21.5 \\
\hline & Student & 22 & 18.2 \\
\hline & Employed & 13 & 10.7 \\
\hline \multirow{4}{*}{ Education } & Primary & 75 & 62 \\
\hline & Secondary & 34 & 28.1 \\
\hline & University & 2 & 1.7 \\
\hline & None & 10 & 8.3 \\
\hline \multirow[t]{2}{*}{ Health care } & Contributory & 18 & 14.9 \\
\hline & Subsidized & 103 & 85.1 \\
\hline Sanitary characteristics & & Frequency & Percentage $(\%)$ \\
\hline \multirow[t]{2}{*}{ Washes food before consuming } & Yes & 61 & 50.4 \\
\hline & No & 60 & 49.6 \\
\hline \multirow[t]{2}{*}{ Washes hands after bowel movement } & Yes & 65 & 53.7 \\
\hline & No & 56 & 46.3 \\
\hline \multirow{4}{*}{ Disposal of human waste } & Open field & 91 & 75.2 \\
\hline & Toilet & 27 & 22.3 \\
\hline & Septic tank & 2 & 1.7 \\
\hline & Latrine & 1 & 0.8 \\
\hline \multirow[t]{2}{*}{ Contact with pigs } & Yes & 86 & 71.1 \\
\hline & No & 35 & 28.9 \\
\hline \multirow{2}{*}{ Bathing of pigs } & Yes & 53 & 43.8 \\
\hline & No & 68 & 56.2 \\
\hline \multirow[t]{2}{*}{ Frequency of bathing of pigs } & Weekly & 44 & 36.4 \\
\hline & Over a week & 77 & 63.6 \\
\hline \multirow{2}{*}{ Pigsty cleaning } & Yes & 31 & 25.6 \\
\hline & No & 90 & 74.4 \\
\hline \multirow{2}{*}{ Frequency of cleaning of pigsties } & Daily & 21 & 17.4 \\
\hline & Weekly or longer & 100 & 82.6 \\
\hline \multirow[t]{2}{*}{ Hand washing after cleaning pigsties } & Yes & 33 & 27.3 \\
\hline & No & 88 & 72.7 \\
\hline Cultural characteristics & & Frequency & Percentage (\%) \\
\hline \multirow[t]{2}{*}{ Consumption of pork meat } & Yes & 110 & 90.9 \\
\hline & No & 11 & 9.1 \\
\hline \multirow{4}{*}{ Washing and cooking of pork meat } & Wash & 6 & 5 \\
\hline & Cook & 56 & 46.3 \\
\hline & Wash and cook & 45 & 37.2 \\
\hline & None & 14 & 11.6 \\
\hline \multirow{2}{*}{ Feeds the pigs } & Yes & 81 & 66.9 \\
\hline & No & 40 & 33.1 \\
\hline \multirow[t]{2}{*}{ Boils water for consumption } & Yes & 5 & 4.1 \\
\hline & No & 116 & 95.9 \\
\hline
\end{tabular}


Regarding seroprevalence of anti-cysticercus antibodies, our results show that 44.6\% (54/121; CI95\%: 36.1- 53.5) of the study population exhibited detectable levels of these antibodies, with a high seroprevalence detected in women $(61,1 \% ; 33 / 54$; CI95\% 47,8-73) and in the 18 to 44 years age group $(32,2 \% ; 39 / 121$; CI 95\% 24,6 - 41). No significant associations between status of seroprevalence and $\operatorname{sex}(X 2=0.0001, \mathrm{p}=0.9926)$ or age $(\mathrm{X} 2=6.44, \mathrm{p}$ $=0.2656$ ) were identified. On the other hand, a significant association was found between presenting anti-cysticercus antibodies and activities such as bathing of the pigs, frequency of bathing, among other variables $(\mathrm{p}<0.05)$ (Table 2).

Table 2. Socioeconomic, sanitary, and cultural characteristics of pig breeders by presence of anti-cysticercus antibodies

\begin{tabular}{|c|c|c|c|c|c|}
\hline \multirow{2}{*}{ Socioeconomic characteristics } & & \multicolumn{2}{|c|}{ Anti-cysticercus antibody } & \multirow{2}{*}{$X^{2}$} & \multirow{2}{*}{$p$} \\
\hline & & Positive $(\%)$ & Negative (\%) & & \\
\hline \multirow{4}{*}{ Occupation } & Independent worker & $7(13 \%)$ & $6(9 \%)$ & \multirow{4}{*}{3.009} & \multirow{4}{*}{0.39} \\
\hline & Unemployed & $30(56 \%)$ & $30(45 \%)$ & & \\
\hline & Student & $7(13 \%)$ & $15(22 \%)$ & & \\
\hline & Employed & $10(18 \%)$ & $16(24 \%)$ & & \\
\hline \multirow{4}{*}{ Education } & Primary & $7(13 \%)$ & $3(5 \%)$ & \multirow{4}{*}{4.337} & \multirow{4}{*}{0.227} \\
\hline & Secondary & $32(59 \%)$ & $43(65 \%)$ & & \\
\hline & University & $15(28 \%)$ & $19(29 \%)$ & & \\
\hline & None & $0(0 \%)$ & $2(3 \%)$ & & \\
\hline \multirow[t]{2}{*}{ Health care } & Contributory & $9(17 \%)$ & $9(13 \%)$ & \multirow{2}{*}{0.247} & \multirow{2}{*}{0.619} \\
\hline & Subsidized & $45(83 \%)$ & $58(87 \%)$ & & \\
\hline \multicolumn{6}{|l|}{ Sanitary characteristics } \\
\hline \multirow[t]{2}{*}{ Washes food before consuming } & Yes & $26(48 \%)$ & $35(52 \%)$ & \multirow{2}{*}{0.2} & \multirow{2}{*}{0.655} \\
\hline & No & $28(52 \%)$ & $32(48 \%)$ & & \\
\hline \multirow[t]{2}{*}{ Washes hands after bowel movement } & Yes & $28(52 \%)$ & $37(55 \%)$ & \multirow{2}{*}{0.137} & \multirow{2}{*}{0.712} \\
\hline & No & $26(48 \%)$ & $30(45 \%)$ & & \\
\hline \multirow{4}{*}{ Fecal waste disposal } & Open field & $43(80 \%)$ & $48(72 \%)$ & \multirow{4}{*}{$\begin{array}{l}3.736 \\
0.291\end{array}$} & \\
\hline & Toilet & $10(18 \%)$ & $17(25 \%)$ & & \\
\hline & Septic tank & $1(2 \%)$ & $0(-)$ & & \\
\hline & Latrine & $0(-)$ & $2(3 \%)$ & & \\
\hline \multirow[t]{2}{*}{ Contact with pigs } & Yes & $46(38 \%)$ & $40(33 \%)$ & \multirow{2}{*}{9.445} & \multirow{2}{*}{$0.0021 *$} \\
\hline & No & $8(6.7 \%)$ & $27(22.3 \%)$ & & \\
\hline \multirow{2}{*}{ Bathing of pigs } & Yes & $30(56 \%)$ & $25(37 \%)$ & \multirow{2}{*}{4.013} & \multirow{2}{*}{$0.045^{*}$} \\
\hline & No & $24(44 \%)$ & $42(63 \%)$ & & \\
\hline \multirow[t]{2}{*}{ Frequency of bathing of pigs } & Weekly & $25(46 \%)$ & $19(28 \%)$ & \multirow{2}{*}{4.157} & $0 \Omega 1 \%$ \\
\hline & Over a week & $29(54 \%)$ & $48(72 \%)$ & & $0.041^{*}$ \\
\hline Pigsty cleaning & Yes & $19(35 \%)$ & $12(18 \%)$ & 4682 & $0030 *$ \\
\hline Pigsty cleaning & No & $35(65 \%)$ & $55(82 \%)$ & 4.682 & $0.030^{*}$ \\
\hline & Daily & $17(54.8 \%)$ & $4(12.9 \%)$ & 3567 & \\
\hline Frequency of cleanıng of pigsties & Weekly or longer & $37(69 \%)$ & $63(94 \%)$ & 13.567 & $0.0002^{*}$ \\
\hline Hand washing after cleaning pigsties & Yes & $19(35 \%)$ & $14(21 \%)$ & 3708 & 0070 \\
\hline & No & $35(65 \%)$ & $53(79 \%)$ & 3.108 & 0.019 \\
\hline
\end{tabular}




\section{Cultural characteristics}

\begin{tabular}{|c|c|c|c|c|c|}
\hline \multirow[t]{2}{*}{ Consumption of pork meat } & Yes & $50(93 \%)$ & $60(90 \%)$ & \multirow{2}{*}{0.334} & \multirow{2}{*}{0.563} \\
\hline & No & $4(7 \%)$ & $7(7 \%)$ & & \\
\hline \multirow{4}{*}{ Washing and cooking of pork meat } & Wash & $1(1.9 \%)$ & $5(7.5 \%)$ & \multirow{4}{*}{2.675} & \multirow{4}{*}{0.444} \\
\hline & Cook & $28(51.8 \%)$ & $28(41.8 \%)$ & & \\
\hline & Wash and cook & $19(35.2 \%)$ & $26(38.8 \%)$ & & \\
\hline & None & $6(11.1 \%)$ & $8(11.9 \%)$ & & \\
\hline \multirow{2}{*}{ Feeds the pigs } & Yes & $45(83 \%)$ & $36(54 \%)$ & \multirow{2}{*}{11.84} & \multirow{2}{*}{$0.001 *$} \\
\hline & No & $9(17 \%)$ & $31(46 \%)$ & & \\
\hline \multirow[t]{2}{*}{ Boils water for consumption } & Yes & $2(4 \%)$ & $3(5 \%)$ & \multirow{2}{*}{0.045} & \multirow{2}{*}{0.832} \\
\hline & No & $52(96 \%)$ & $64(95 \%)$ & & \\
\hline
\end{tabular}

Note. $\mathrm{X}^{2}=$ Chi-squared test, $\mathrm{p}=\mathrm{p}$-value level of significance, ${ }^{*}$ statistically significant $\mathrm{p}<0.05$.

Calculation of raw association showed OR for variables such as contact with pigs, bathing of pigs, weekly frequency of bathing, cleaning of pigsties, and feeding of pigs (Table 3). However, when adjusting by applying multivariate logistic regression model, a causal association was identified for daily cleaning of the pigsties $(\mathrm{aOR}=$ 15. 16; CI 95\%: 2.13 - 107.86; $p=0$.0002), suggesting that individuals cleaning pigsties have a fifteen times greater risk of presenting anti-cysticercus antibodies (Table 3).

Table 3. Raw and adjusted OR

\begin{tabular}{|c|c|c|c|c|c|c|}
\hline \multirow{2}{*}{ Characteristics } & \multicolumn{2}{|c|}{ Anti-cysticercus antibody } & \multirow{2}{*}{ OR } & \multirow{2}{*}{ CI $95 \%$} & \multirow{2}{*}{$\mathrm{aOR}$} & \multirow{2}{*}{ CI 95\% } \\
\hline & Positive & Negative & & & & \\
\hline Contact with pigs & 46 & 40 & 3.881 & $1.49-10.93$ & 1.17 & $0.23-5.89$ \\
\hline Bathing of pigs & 30 & 25 & 2.1 & $0.95-4.65$ & 0.98 & $0.21-4.66$ \\
\hline Weekly bathing of pigs & 25 & 19 & 2.177 & $0.96-4.96$ & 1.13 & $0.23-5.53$ \\
\hline Pigsty cleaning & 19 & 12 & 2.49 & $1.00-6.33$ & 1.12 & $0.04-34.04$ \\
\hline Daily pigsty cleaning & 17 & 4 & 7.24 & $2.11-31.29$ & 15.16 & $2.13-107.86$ \\
\hline Feeding of pigs & 45 & 36 & 4.305 & $1.71-11.52$ & 2.92 & $0.61-13.98$ \\
\hline
\end{tabular}

Note. $\mathrm{OR}=$ Odds Ratio, $\mathrm{CI}=$ confidence interval, $\mathrm{aOR}=$ adjusted Odds Ratio.

Clinical manifestations suggestive of cysticercosis were evaluated in pig breeders, of which fever and headache were the most frequently found (Table 4). A statistically significant association was found between double vision and anti-cysticercus antibodies $(\mathrm{p}=0.036)$.

Table 4. Clinical manifestations according to anti-cysticercus antibody status

\begin{tabular}{|c|c|c|c|c|c|}
\hline \multirow[t]{2}{*}{ Clinical manifestations } & & \multicolumn{2}{|c|}{ Anti-cysticercus antibody } & \multirow{2}{*}{$X^{2}$} & \multirow{2}{*}{$p$} \\
\hline & & Positive (\%) & Negative (\%) & & \\
\hline \multirow{2}{*}{ Visual impairment } & Yes & $1(2 \%)$ & $2(3 \%)$ & \multirow{2}{*}{0.1588} & \multirow{2}{*}{0.6903} \\
\hline & No & $53(98 \%)$ & $65(97 \%)$ & & \\
\hline \multirow{2}{*}{ Fever } & Yes & $31(57 \%)$ & $30(45 \%)$ & \multirow{2}{*}{1.908} & \multirow{2}{*}{0.167} \\
\hline & No & $23(43 \%)$ & $37(55 \%)$ & & \\
\hline \multirow{2}{*}{ Vomit } & Yes & $9(17 \%)$ & $4(6 \%)$ & \multirow{2}{*}{3.568} & \multirow{2}{*}{0.059} \\
\hline & No & $45(83 \%)$ & $63(94 \%)$ & & \\
\hline
\end{tabular}




\begin{tabular}{|c|c|c|c|c|c|}
\hline \multirow{2}{*}{ Double vision } & Yes & $1(2 \%)$ & $8(12 \%)$ & \multirow{2}{*}{4.42} & \multirow{2}{*}{$0.036^{*}$} \\
\hline & No & $53(98 \%)$ & $59(88 \%)$ & & \\
\hline \multirow[t]{2}{*}{ Tremor } & Yes & $1(2 \%)$ & $4(6 \%)$ & \multirow{2}{*}{1.28} & \multirow{2}{*}{0.258} \\
\hline & No & $53(98 \%)$ & $63(94 \%)$ & & \\
\hline \multirow{2}{*}{ Epilepsy } & Yes & $2(4 \%)$ & $0(-)$ & \multirow{2}{*}{2.523} & \multirow{2}{*}{0.112} \\
\hline & No & $52(96 \%)$ & $67(100 \%)$ & & \\
\hline \multirow{2}{*}{ Diarrhea } & Yes & $8(15 \%)$ & $17(25 \%)$ & \multirow{2}{*}{2.033} & \multirow{2}{*}{0.154} \\
\hline & No & $46(85 \%)$ & $50(75 \%)$ & & \\
\hline \multirow{2}{*}{ Headache } & Yes & $43(80 \%)$ & $46(69 \%)$ & \multirow{2}{*}{1.851} & \multirow{2}{*}{0.174} \\
\hline & No & $11(20 \%)$ & $21(31 \%)$ & & \\
\hline \multirow{2}{*}{ Memory loss } & Yes & $6(11 \%)$ & $8(12 \%)$ & \multirow{2}{*}{0.02} & \multirow{2}{*}{0.887} \\
\hline & No & $48(89 \%)$ & $59(88 \%)$ & & \\
\hline
\end{tabular}

Note. $\mathrm{X}^{2}=$ Chi-squared test, $\mathrm{p}=\mathrm{p}$-value level of significance, *statistically significant $\mathrm{p}<0.05$.

Similarly, the presence of anti-cysticercus antibodies and other variables were also analyzed in pigs (Table 5). The predominant breed was the creole $(85.8 \%, 218 / 254$ CI $95 \% 81-89.6)$, and the majority of pigs were female (75.2\%, 151/254 CI 95\% 53. 3 - 65. 3). Anti-cysticercus antibodies were detected in 36.6\% (93/254 CI 95\% 30. 9 - 42.7) of the analyzed porcine sera. No significant association was identified between presence of antibodies and other variables $(\mathrm{p}>0.05)$.

Table 5. Characteristics of the analyzed porcine population by anti-cysticercus antibody status

\begin{tabular}{|c|c|c|c|c|c|}
\hline \multirow{2}{*}{ Characteristics } & & \multicolumn{2}{|c|}{ Anti-cysticercus antibodies } & \multirow{2}{*}{$X^{2}$} & \multirow{2}{*}{$p$} \\
\hline & & Positive (\%) & Negative (\%) & & \\
\hline \multirow{4}{*}{ Breed } & Yorkshire & $1(1.1 \%)$ & $3(1.9 \%)$ & \multirow{4}{*}{0.729} & \multirow{4}{*}{0.866} \\
\hline & Creole & $82(88.2 \%)$ & $136(84.5 \%)$ & & \\
\hline & Duroc & $1(1.1 \%)$ & $2(1.2 \%)$ & & \\
\hline & Pietrain & $9(9.6 \%)$ & $20(12.4 \%)$ & & \\
\hline \multirow{2}{*}{ Sex } & Female & $71(76.3 \%)$ & $120(74.5 \%)$ & \multirow{2}{*}{0.104} & \multirow{2}{*}{0.748} \\
\hline & Male & $22(23.7 \%)$ & $41(25.5 \%)$ & & \\
\hline \multirow{2}{*}{ Age (years) } & $1-2.5$ & $91(97.8 \%)$ & $155(96.3 \%)$ & \multirow{2}{*}{0.48} & \multirow{2}{*}{0.488} \\
\hline & $2.5-5$ & $2(2.2 \%)$ & $6(37.3 \%)$ & & \\
\hline \multirow[t]{2}{*}{ Human responsible for pig } & Woman & $62(66.7 \%)$ & $101(62.7 \%)$ & \multirow{2}{*}{0.397} & \multirow{2}{*}{0.529} \\
\hline & Man & $31(33.3 \%)$ & $60(37.3 \%)$ & & \\
\hline \multirow{2}{*}{ Breeding site } & Backyard & $73(78.5 \%)$ & $136(84.5 \%)$ & \multirow{2}{*}{1.445} & \multirow{2}{*}{0.229} \\
\hline & Other site & $20(21.5 \%)$ & $25(15.5 \%)$ & & \\
\hline \multirow{2}{*}{ Pig diet } & Concentrate & $29(31.2 \%)$ & $63(39.1 \%)$ & \multirow{2}{*}{1.612} & \multirow{2}{*}{0.204} \\
\hline & Left overs & $64(68.8 \%)$ & $98(60.9 \%)$ & & \\
\hline \multirow{2}{*}{ Deworming } & Yes & $73(78.5 \%)$ & $141(87.6 \%)$ & \multirow{2}{*}{3.665} & \multirow{2}{*}{0.056} \\
\hline & No & $20(21.5 \%)$ & $20(12.4 \%)$ & & \\
\hline
\end{tabular}

Note. $\mathrm{X}^{2}=$ Chi-squared test, $\mathrm{p}=\mathrm{p}$-value level of significance. 


\section{Discussion}

Cysticercosis is frequent in rural areas since it is associated with breeding of pigs under poor sanitary and environmental conditions, and low educational and socioeconomic level (Villalobos et al., 2007; Toquero, Morocoima \& Ferrer, 2017; Maya et al., 2003). These conditions are all evidenced in María La Baja - Bolívar, since the highest educational level achieved by the majority of pig breeders $(62 \%)$ was up to primary level, and their access to healthcare services was through subsidized regime.

Detection of serologic IgG antibodies is a useful tool in epidemiological studies to identify critical groups in the transmission of this parasitic disease (Manchon, 2009; Del Bruto, 2005). Anti-cysticercus antibody seroprevalence found in pig breeders was $44.6 \%$, which is higher than the reported average of $8.55 \%$ for Colombia, of $35.05 \%$ for the Departament of Bolívar, and the low prevalence of $4.02 \%$ reported for the Department of Boyacá (4.02\%) (Flórez, Pastrán, \& Vargas, 2011). While low seroprevalence of anti-cysticercus antibodies has been reported by other authors (Villalobos et al., 2007; Ferrer et al., 2003; Franco, Giraldo, \& Vásquez, 2013), a seroprevalence of $79 \%$ was also reported by Ferrer (2002) in Native Americans in the state of Amazon, Venezuela.

In this study, higher levels of anti-cysticercus antibodies were detected in participants belonging to the 18 to 44 years age group, and in the female gender group (61.1\%), which is consistent with previous national and international reports (Zamora, 2015; Flórez et al., 2011; Ayala, Medina, \& Morales, 2014; Huete, Durán, \& Soto, 2013). On the other hand, significant associations between socioeconomic factors, such as low educational level, and presence of anti-cysticercus antibodies has been previously reported throughout the literature, in our study such associations were not statistically significant $(p=0.227$ (Rojas et al., 2007).

Increased risk of cysticercosis in humans has been associated to cultural and sanitary conditions such as breeding of pigs in contact with human feces, not washing food before eating, poor hand washing habits, and ingestion of raw or undercooked pork meat. Human beings may acquire cysticercosis by ingestion of $T$. solium eggs directly or indirectly through the fecal-oral route by consuming contaminated water or food. Similarly, pigs that are not kept in pigsties may become infected by unintentional ingestion of contaminated human feces disposed of in open fields or in latrines (Flórez et al., 2011; Rincón \& Flórez, 2009; Rojas et al., 2007; Giraldo, Riaño \& Vásquez, 2017; Flisser, Sarti, Lightowlers, \& Schahtz, 2003; Díaz et al., 1992).

Pig breeders in Maria La Baja are exposed to all of these risky conditions; they exhibited habits such as disposing of human feces in an open field (75.2\%), which favors porcine infection; a substantial proportion of them did not wash their food before consumption (49.6\%), nor washed their hands after bowel movements $(46.3 \%)$ or after bathing pigs (72.7\%). The analyzed cultural characteristics were not associated to seroprevalence ( $>0.05)$, even when these are important transmission factors for this infection. However, our results are comparable to those reported by another Colombian study for the general population in Mitú, Department of Vaupés in 2009 (Rincón \& Flórez, 2009).

Logistic regression analysis showed that daily cleaning of pigsties is a predictive variable of antibody seroprevalence in human beings (Sanitary characteristic, aOR $=15.16$ CI 95\%: $2.13-107.86 ; p=0.0002$ ); suggesting that individuals performing daily cleaning of pigsties are at 15 times greater risk of presenting anti-cysticercus antibodies. The contamination of breeders may be explained by the lack of use of personal protection equipment while cleaning the pigsties. Villalobos and colleagues (2007) reported similar observations in pig farm workers and pig breeders in Mara, Venezuela.

Symptoms commonly observed in cysticercosis include seizures, nausea, vomiting, headache, ataxia, and confusion (Pal, Carpio, \& Sander, 2000). Analysis of such symptoms in breeders showed that in our study population the most frequent one was headache $(80 \%)$, which is in agreement with a previous study of anti-cysticercus antibody seroprevalence in Colombia by Flórez (2013). In addition, we identified a significant association between double vision and presence of anti-cysticercus antibodies $(\mathrm{p}=0.036)$, and other authors reported the association of additional clinical manifestations with antibody seroprevalence (Rincón, \& Flórez, 2009; Solís, Tello, Quispe, \& Ramírez, 2007).

While pig breeding is an important economic activity for farmers, including those residing in Maria La Baja, this activity may facilitate ingestion of $T$. solium eggs and the subsequent development of cysticercosis in pigs that are exposed to human feces. Therefore, porcine cysticercosis is considered as an epidemiologic indicator of transmission intensity (Arroyo, 2010).

In the porcine population in this study, anti-cysticercus antibodies, breed, sex, breeding site, diet, and age were evaluated. Of the analyzed pigs, anti-cysticercus antibodies were detected in $36.6 \%$ of them, which is higher than that reported for the Department of Cauca in 2003, in which seropositivity was reduced from $16 \%$ to $8.6 \%$ 
(Vásquez et al., 2011). On the other hand, a lower prevalence has been reported by additional studies (Arroyo, 2010; Molano, Andrade \& Giraldo, 2009). With regards to pig gender, seropositivity was greater in females (76,3\%); consistent with what was described in a study in Sogamoso, Department of Boyacá (80.2\%) (Molano, Andrade, \& Giraldo, 2009). The identified prevalence of porcine cysticercosis in our study was higher than that reported by other international studies (Nguhiu, Kamau, Kinyua, \& Matonge, 2017; Kungu, Dione, Ejobi, Ocaido, \& Grace, 2017).

One of the limitations of this study is the dependence on participants' retrospective memory when answering the questionnaire, since it may have led to imprecisions or omission of relevant information.

In summary, our results indicate that pig breeders in Maria La Baja exhibit a high prevalence of anti-cysticercus antibodies; a significant increased risk for seropositivity associated to daily cleaning of pigsties; and headache as the most common symptom in seropositive individuals. In pigs, similarly, a high prevalence of anti-cysticercus antibodies was identified, of which those of creole breed were the most frequently found to be seropositive. Deficiencies in pigsties' sanitary conditions, educational level of breeders, and cultural characteristics have an effect on the identified high prevalence of anti-cysticercus antibodies. Our results suggest that there is a need to design and implement prevention and control strategies in Maria La Baja in order to reduce transmission of this disease.

\section{Competing Interests Statement}

The authors declare that there are no competing or potential conflicts of interest.

\section{References}

Agudelo, P., \& Palacio, L. (2003). Prevalencia de anticuerpos para Taenia solium en humanos y cerdos en una zona endémica Colombiana. Revista de Neurología, 36:706-709.

Alcaldia Municipal de María La Baja Bolívar. Plan de Desarrollo "Un pueblo educado asegura su desarrollo" 2016- 2019. María la baja si avanza. Retrieved December 18 2017, from: http://www.marialabaja-bolivar.gov.co/Transparencia/PlaneacionGestionyControl/Plan\%20de\%20Desarroll о\%20Mar\%C3\%ADa\%20La\%20Baja\%20\%202016\%20-\%202019.pdf

Arroyo, G. (2010). Epidemiología serológica de la cisticercosis porcina en el Perú. Epidemiología Serológica de la Cisticercosis Porcina en el Perú. Retrieved from https://ecitydoc.com/download/epidemiologia-serologica-de-la-cisticercosis-porcina-en-el-peru_pdf

Ayala, E., Medina, S., \& Morales, J. (2014). Cisticercosis humana y su asociación con factores epidemiológicos y clínicos en los Andes centro y sur de Perú, 2000-2001. Revista Peruana de Epidemiología, 18(1), 1-6.

Del Brutto, O. (2005). Neurocisticercosis: actualización en el diagnóstico y tratamiento. Neurología, 20, 412-418.

Diaz, F., Garcia, H. H., Gilman, R. H., Gonzales, A. E., Castro, M., Tsang, V. C. W., ... \& Madico, G. (1992). Epidemiology of taeniasis and cysticercosis in a Peruvian village. American Journal of Epidemiology, 135(8), 875-882. https://doi.org/10.1093/oxfordjournals.aje.a116383

Ferrer, E., Cabrera, Z., Rojas, G., Lares, M., Vera, A., de Noya, B. A., ... \& Cortez, M. M. (2003). Evidence for high seroprevalence of Taenia solium cysticercosis in individuals from three rural communities in Venezuela. Transactions of the Royal Society of Tropical Medicine and Hygiene, 97(5), 522-526. https://doi.org/10.1016/S0035-9203(03)80014-7

Ferrer, E., Cortez, M. M., Perez, H., De la Rosa, M., de Noya, B. A., D'Avila, I., ... \& Cabrera, A. (2002). Serological evidence for recent exposure to Taenia solium in Venezuelan Amerindians. The American journal of tropical medicine and hygiene, 66(2), 170-174. https://doi.org/10.4269/ajtmh.2002.66.170

Flisser, A., Sarti, E., Lightowlers, M., \& Schantz, P. (2003). Neurocysticercosis: regional status, epidemiology, impact and control measures in the Americas. Acta tropica, 87(1), 43-51. https://doi.org/10.1016/S0001-706X(03)00054-8

Flórez, A. C., Pastrán, S. M., Peña, A. P., Benavides, A., Villarreal, A., Rincón, C. E., ... \& Guasmayan, L. (2011). Cisticercosis en Boyacá, Colombia: estudio de seroprevalencia. Acta Neurol Colomb, 27(1), 9-18.

Flórez, A., Pastrán, S., Vargas, N., Beltran, M., Enriquez, Y., Pe-a, A., Villareal, A., ... Hernandez, N. (2013). Cisticercosis en Colombia Estudio de seroprevalencia 2008-2010. Acta Neurológica Colombiana, 29(2), 73-86.

Franco, C., Giraldo, J., \& Vasquez, L. (2013). Detección de anticuerpos onticisticerco en pacientes que asistieron a 
consulta médica durante el periodo 2009 - 2010 a la Liga Contra la Epilepsia Capítulo Cauca. Revista Cientifica UNNINCA, 18(1), 79-93.

Giraldo, J., Piragauta, M., Casta-eda, H., Burgos, J., \& Marinkelle, C. (2000). Valoración de la inmunodominancia de tres fracciones proteicas $(64.53$ y $32 \mathrm{kDa})$ obtenidas a partir de un extracto crudo del metacéstodo de Taenia solium con sueros porcinos. Revista Científica de Unincca, 6(1), 19-34.

Giraldo, J., Ria-o, M., \& Vásquez, L. (2017). Determinación de la seroprevalencia de cisticercosis porcina e identificación de teniasis humana en personas criadoras de cerdos en el área urbana del municipio de Coyaima Tolima. Revista MED, 25(1), 32-45. https://doi.org/10.18359/rmed.2916

Huete, F., Durán, O., \& Soto, C. (2013). Neurocisticercosis. Revista Médica de Costa Rica y Centroamérica, 70, 467-473.

Kungu J., Dione M., Ejobi F., Ocaido M., Grace D. (2017). Risk factors, perceptions and practices associated with Taenia solium cysticercosis and its control in the smallholder pig production systems in Uganda: a cross-sectional survey. BMC Infectious Diseases, 17, 1. https://doi.org/10.1186/s12879-016-2122-x

Manchon, F. (2009). Encuestas seroepidemiológicas en enfermedades no inmunoprevenibles y su interés en Salud $\begin{array}{lllll}\text { Pública. Revista Espa-ola de Salud Pública, 83(5), 645-657. } & \text {. }\end{array}$ https://doi.org/10.1590/S1135-57272009000500006

Maya J., Aluja A., Avila G., Vega L., Plancarte A., Arango C. (2003). Teniosis y detección de anticuerpos anticisticerco en personas de una comunidad rural del estado de Guerrero. Salud Pública de México, 45(2), 84-89.

Molano, D., Andrade, R., \& Giraldo, J. (2009). Determinación serológica de cisticercosis porcina en la planta de sacrificio del municipio de Sogamoso (Boyacá). Revista Colombiana de Ciencias Pecuarias, 22(3), 551.

Nguhiu, P., Kamau, L., Kinyua, K., \& Matonge, P. (2017). Seroprevalence of Porcine Cysticercosis and Associated Risk Factors in Pigs Slaughtered in Abattoirs in Thika, Kiambu County, Kenya. Journal of Life Sciences, 11, 321- 326. Dhttps://doi.org/10.17265/1934-7391/2017.07.002

Pal, D., Carpio, A., \& Sander, J. (2000). Neurocysticercosis and epilepsy in developing countries. Journal of Neurology, Neurosurgery, and Psichiatry, 68(2), 137-143. https://doi.org/10.1136/jnnp.68.2.137

Rincón, C., \& Flórez, A. (2009). Factores de riesgos asociados a la seroprevalencia de cisticercosis en el municipio de Mitú, Colombia. Nova, 7, 143-147. https://doi.org/10.22490/24629448.428

Rojas, G., Aguilar, C., Ferrer, E., Alvarez, Y., Parkhouse, M., \& Cortés, M. (2007). Cisticercosis humana: una dolencia olvidada. Salus, 11, 53-56.

Rojas, G., Aguilar, C., Ferrer, E., Alviarez, Y., Parkhouse, M., Cortéz, M. (2007). Cisticercosis Humana: una Dolencia Olvidada. SALUS Revista De La Facultad De Ciencias De La Salud. Universidad de Carabobo, 11, 53- 56.

Serrano, J., Prada, F., Nicholls, R., Duque, S., \& López, M. (1993). Determinacion de la prevalencia de cisticercosis porcina en cuatro veredas del municipio de Coyaima. Biomédica, 13(3), 129-135. https://doi.org/10.7705/biomedica.v13i3.2058

Solís, A., Tello, T., Quinte, D., \& Ramírez, S. (2007). Prevalencia y factores de riesgo asociados a neurocisticercosis en trabajadores del camal Conchucos, El Agustino, Perú. Acta Médica Peruana, 24, 167-171.

Toquero, M., Morocoima, A., Ferrer, E. (2017). Seroprevalencia y factores de riesgo de cisticercosis en dos comunidades rurales del norte del estado Anzoátegui, Venezuela. Biomédica, 37(Sp.1), 66-74. https://doi.org/10.7705/biomedica.v37i2.2841

Vásquez, L., Giraldo, J., Agúdelo, P., Campo, V., \& Vergara, D. (2011). Experiencia para el control de la cisticercosis en el departamento del Cauca. Biomédica, 31(sup.3), 3-315.

Villalobos, R., Cheng, R., Díaz, O., Estévez, J., Beauchamp, S., Cava J. (2007). Seroprevalencia y factores de riesgo de cisticercosis en trabajadores de granjas y criadores de cerdos artesanales del municipio de Mara, estado Zulia, Venezuela. Kasmera, 35, 26-37.

World Health Organization [Internet]. Teniasis y Cisticercosis; 2016. Retrieved November 30, 2017, from http://www.who.int/mediacentre/factsheets/fs376/es/

Zamora, T. (2015). Neurocisticercosis: enfermedad desatendida en Colombia. Morfolia, 7, 26-27. 


\section{Copyrights}

Copyright for this article is retained by the author(s), with first publication rights granted to the journal.

This is an open-access article distributed under the terms and conditions of the Creative Commons Attribution license (http://creativecommons.org/licenses/by/4.0/). 